\title{
EFFECTS OF ORGANIC LOADING RATE AND HYDRAULIC RETENTION TIME ON TREATMENT OF PHENOLIC WASTEWATER IN AN ANAEROBIC IMMOBILIZED FLUIDIZED BED REACTOR
}

\author{
Roya Pishgar $^{\mathrm{a}}$, Ghasem D. Najafpour ${ }^{\mathrm{b}}$, Bahram Navayi Neya ${ }^{\mathrm{a}}$, Nafise Mousavi ${ }^{\mathrm{a}}$, \\ Zeinab Bakhshi ${ }^{\mathrm{a}}$ \\ ${ }^{a}$ School of Civil Engineering, Babol Noshirvani University of Technology, Babol, Mazandaran, Iran \\ ${ }^{b}$ Biotechnology Research Center, Faculty of Chemical Engineering, Babol Noshirvani University of \\ Technology, Babol, Babol, Iran
}

Submitted 26 Jul. 2012; accepted 24 Apr. 2013

\begin{abstract}
Treatability of phenolic wastewater in an anaerobic immobilized fluidized bed reactor (AIFBR) in consequence of stepwise increment in phenolic load as well as decrease in hydraulic retention time (HRT) was investigated. The experimental data indicated that high degradation efficiencies of phenol and COD in the bioreactor at low HRTs and high organic loading rates were obtained. At constant HRT of $16 \mathrm{~h}$ with increase in influent phenol concentration from 98 to $630 \mathrm{mg} / \mathrm{l}$, the average phenol and COD removals were 96 and $88 \%$, respectively. However, further increase in phenol concentration in the feed stream to $995 \mathrm{mg} / \mathrm{l}$ resulted in decrease in phenol and COD removal efficiencies to 84 and $79 \%$, respectively. For influent phenol concentration of $995 \mathrm{mg} / \mathrm{l}$, the biogas production rate of 4.55 1/l.d was obtained. As HRT decreased from 3 to 0.15 day, the system showed high stability; influent phenol and COD were removed and reached to average values of 17 and $173 \mathrm{mg} / \mathrm{l}$ correspond to the removal efficiencies of about 97 and $90.5 \%$, respectively. The bioreactor experienced a failure with further decrease in HRT to 0.1 day. Biogas production was gradually decreased from 7.04 1/l.d at HRT of 3 days to 2.23 1/l.d at HRT of 0.1 days. The value of the ratio of volatile fatty acids to total alkalinity (VFAs/TA) ranged from 0.03 to 0.24 during the entire course of operation. Keywords: biotechnologies in environmental engineering, wastewater management.

Reference to this paper should be made as follows: Pishgar, R.; Najafpour, G. D.; Navayi Neya, B.; Mousavi, N.; Bakhshi, Z. 2014. Effects of organic loading rate and hydraulic retention time on treatment of phenolic wastewater in an anaerobic immobilized fluidized bed reactor, Journal of Environmental Engineering and Landscape Management 22(1): 40-49. http://dx.doi.org/10.3846/16486897.2013.800079
\end{abstract}

\section{Introduction}

One of the most important challenges of modern world is to preserve the environment against diverse pollutions. Progressive industrialization is the major reason of releasing different types of contaminants into ecosystem (Kwon et al. 2009; Mousavi et al. 2011). Phenol and its derivatives which are known as toxic carcinogenic aromatics abundantly occur in environment by disposal of phenol-containing effluents of number of industries. Some of these industries are petroleum refineries, steel plants, pulp and paper, pharmaceuticals, manufacturing of synthetic chemicals, coal conversion, coke oven, etc (Arutchelvan et al. 2006; Fang et al. 2006; Carbajo et al. 2010). High concentrations of phenol (up to 17,500 mg/l) have been detected in various industrial wastewaters (Carbajo et al. 2010). The reported range of phenol concentrations in various industrial wastewaters are summarized in
Table 1 (Carlo et al. 2008). Specific low concentration of phenol poses significant health and environmental risks for human (Rittmann et al. 2001; El-Naas et al. 2009). Hence, phenolic compounds have been regarded as priority organic pollutant by US Environmental Protection Agency (U. S. EPA). In addition, World Health Organization (WHO) has defined permissible level of $1 \mu \mathrm{g}$ phenol per liter of drinking water (Nuhoglu et al. 2005; Yan et al. 2006). Considering noxious affects of phenol, phenolic wastewaters must be treated before being discharged to the surrounding environment (Yan et al. 2005).

Different physicochemical or conventional biological methods can be employed to reduce phenol content below permitted level (Gonzalez et al. 2001a; Carlo et al. 2008). Bioprocesses are proven to be cost-effective environmentally-friendly approaches in which complete mineralization of organic contaminants may occur 
Table 1. Phenol concentration in various industrial wastewaters

\begin{tabular}{lc}
\hline Wastewater & Phenol concentration $(\mathrm{mg} / \mathrm{l})$ \\
\hline Refineries & $6-500$ \\
Coking operations & $28-3900$ \\
Coal processing & $9-6800$ \\
Petrochemicals & $2.8-1220$ \\
Pulp and paper & $0.1-1600$ \\
Pharmaceutical & $0.1-1600$ \\
Synthetic wastewater & $98-995$ \\
(this study) & \\
\hline
\end{tabular}

(Moussavi et al. 2009; Firozjaee et al. 2011). Moreover, treatment of phenolic wastewater using physicochemical techniques may result in production of toxic byproducts such as poisonous poly chlorinated phenols. Therefore, phenol biodegradation is preferred in comparison to chemical oxidizing or physical treatment as transferring pollution from one phase to another (Arutchelvan et al. 2006; Bakhshi et al. 2011).

Phenol removal in presence of oxygen is often preferred due to high phenol inhibition on anaerobic processes. However, complete degradation of phenol can happen in anaerobic systems by a well acclimated culture (Moussavi et al. 2009). Aerobic treatment of phenolic wastewater is extensively discussed in the literature (Gonzalez et al. 2001a; Gonzalez et al. 2001b; Alemzadeh et al. 2002; Tziotzios et al. 2005; Vázquez et al. 2006; Nair et al. 2007; Moussavi et al. 2009). Though, in late decades there is a widespread tendency to apply anaerobic biological treatment systems for treating different types of wastewaters (Șen et al. 2003; Bertin et al. 2004; Subramanyam et al. 2008; Asadi et al. 2009a; Asadi et al. 2009b; Carbajo et al. 2010; Saghafi et al. 2010; Wang et al. 2010). Anaerobic biodegradation is being favored to aerobic systems due to low energy and nutrient requirements and less sludge yield (Metcalf et al. 2003; Veeresh et al. 2005; Carbajo et al. 2010). Besides, methane can be produced throughout anaerobic digestion which is considered as an innovative energy source (Metcalf et al. 2003; Bakhshi et al. 2011). Table 2 listed the conducted researches on anaerobic biodegradation of phenolic wastewaters reported in the literature. Among several high rate biological processes, fluidized bed reactor (FBR) is an advanced technique with relatively low hydraulic retention times. Considering slow growth of anaerobic consortia, FBR as a novel technology provides appropriate bioreactor volume as well as high active biomass concentration. Due to

Table 2. Studies of anaerobic biodegradation of phenolic compounds

\begin{tabular}{|c|c|c|c|c|c|c|c|c|}
\hline Substrate & $\begin{array}{l}\text { Phenolic } \\
\text { compound } \\
(\mathrm{mg} / \mathrm{l})\end{array}$ & $\begin{array}{l}\text { COD } \\
(\mathrm{mg} / \mathrm{l})\end{array}$ & $\begin{array}{c}\text { OLR } \\
\text { (g COD/ } \\
\text { l.d) }\end{array}$ & $\begin{array}{l}\text { Phenolic } \\
\text { compound } \\
\text { removal } \\
(\%)\end{array}$ & $\begin{array}{c}\text { COD } \\
\text { removal } \\
(\%)\end{array}$ & $\begin{array}{l}\text { HRT } \\
\text { (day) }\end{array}$ & Reactor $^{\mathrm{e}}$ & Ref. \\
\hline p-nitrophenol & $10-700$ & 3000 & $2.89 \times 10^{-4}$ & $\geq 99$ & $\geq 90$ & 10.38 & $\mathrm{ABR}$ & Kuscu et al. 2005 \\
\hline Resorcinol & $212-1038$ & $443-1892$ & $1.91-12.34$ & $81-97$ & $78-94$ & $0.125-0.25$ & FFFB & Latkar et al. 2003 \\
\hline Catechol & $97-1018$ & $188-1897$ & $0.88-13.88$ & $57-91$ & $56-87$ & & & \\
\hline Hydroquinone & $158-903$ & $426-1777$ & $1.88-12.05$ & $32-79$ & $29-83$ & & & \\
\hline $\mathrm{OMW}^{\mathrm{a}}$ & $720-1300$ & $10250-25500$ & $4.34-17.70$ & $\begin{array}{l}66-75 \\
5-32\end{array}$ & $\begin{array}{l}32-65 \\
4-18\end{array}$ & 0.042 & $\begin{array}{l}\text { UAPB-GAC } \\
\text { UAPB-SB }\end{array}$ & Bertin et al. 2004 \\
\hline Phenol & $100-1000$ & $250-2500$ & $0.25-2.5$ & 94 & 88 & 1 & UAPB & Bakhshi et al. 2011 \\
\hline Phenol & $500-1000$ & 5000 & - & $\geq 83$ & $\geq 60$ & 0.5 & EGSB & Scully et al. 2006 \\
\hline $\mathrm{CGW}^{\mathrm{b}}$ & $143-540$ & $1000-2500$ & $1.0-2.5$ & $63 \geq$ & $60 \geq$ & 1 & UASB & Wang et al. 2010 \\
\hline 4-chlorophenol & 40 & $1124-1738$ & $1.7-5.3$ & $82-90$ & $\geq 90$ & $0.25-0.67$ & UASB & $\begin{array}{l}\text { Majumder et al. } \\
2008\end{array}$ \\
\hline Catechol & $100-1500$ & - & $3.77-10.52$ & $\geq 95$ & $\geq 95$ & 0.33 & UASB & $\begin{array}{l}\text { Subramanyam et al. } \\
2007\end{array}$ \\
\hline Phenol & $252-1176$ & $1000-6500$ & $2-18$ & 84-99.9 & $74-91.3$ & $0.33-1$ & UASB & Gali et al. 2006 \\
\hline Phenol & $2080 \geq$ & - & $15.46 \geq$ & $\geq 99.9$ & - & 0.43 & AFBR & Carbajo et al. 2010 \\
\hline $\mathrm{PCP}^{\mathrm{c}}$ & $1333 \geq$ & - & - & $\geq 99.9$ & $\geq 98$ & $0.39-1.55$ & AFBR & $\begin{array}{l}\text { Khodadoust et al. } \\
1997\end{array}$ \\
\hline $\mathrm{PCP}+\mathrm{PAHs}^{\mathrm{d}}$ & $\begin{array}{l}100+ \\
0.5-690\end{array}$ & - & - & $\geq 99.8$ & - & $0.097-0.39$ & AFBR & Koran et al. 2001 \\
\hline Phenol & $98-995$ & $234-2390$ & $0.35-12.25$ & $84-98$ & $79-91$ & $0.15-3$ & AIFBR & This study \\
\hline
\end{tabular}

${ }^{\mathrm{a}}$ Olive mill wastewater

${ }^{\mathrm{b}}$ Coal conversion wastewater

${ }^{\mathrm{c}}$ Pentachlorophenol

${ }^{\mathrm{d}}$ Poly aromatic hydrocarbons (PAHs) such as naphthalene, acenaphthene, pyrene and benzo(b)fluoranthene

e ABR: Anaerobic baffled reactor, FFFB: Fixed film-fixed bed bioreactor, UAPB-GAC: Upflow anaerobic packed bed reactor filled with granular activated carbon, UAPB-SB: Upflow anaerobic packed bed reactor filled with silica beads, EGSB: Expanded granular sludge bed-based bioreactor, UASB: Upflow anaerobic sludge blanket, AFBR: Anaerobic fluidized bed bioreactor; AIFBR: Anaerobic immobilized fluidized bed bioreactor 
adhesion of microorganisms to a solid support, the sludge retention time and the hydraulic residence time are uncoupled in this process. Thus, application of high organic loading rates (OLR) is feasible in such system (Şen et al. 2003; Carbajo et al. 2010; Bakhshi et al. 2011). FBR has been successfully used to treat a broad spectrum of either readily or hardly biodegradable wastes in addition to hazardous pollutants (Borja et al. 1995; Perez et al. 2007; Lohi et al. 2008; Sowmeyan et al. 2008; Kuyukina et al. 2009).

The literature survey reveals that treatment of phenolic wastewater in anaerobic immobilized fluidized bed reactor (AIFBR) is rarely carried out. In this study performance of a laboratory-scale AIFBR on treatment of synthetic wastewater containing high concentrations of phenol was evaluated. The present research was aimed at investigating the effect of increasing phenolic and organic loading rate and decreasing HRT on phenol and COD removal as well as biogas production. Simultaneously variation of $\mathrm{pH}$, VFAs and alkalinity of wastewater were monitored in the entire operation period. The results may be customized for optimizing the operation of a full-scale wastewater treatment plant treating phenolic effluents.

\section{Materials and methods}

\subsection{Fluidized bed bioreactor}

Continuous biodegradation of phenol was accomplished using an anaerobic immobilized fluidized bed reactor (AIFBR). A laboratory-scale configuration was used as experimental setup (Fig. 1). The system consisted of a $7.4 \mathrm{~cm}$ internal diameter and $114.5 \mathrm{~cm}$ long cylindrical Plexiglas column to form the 5.24 1 reactor. The reactor was filled with mature immobilized microorganisms entrapped in calcium alginate gel beads up to $30 \%$ of its total volume. The working volume of the reactor was about 3.51 . The flow was continuously fed into the reactor from a conical section at the bottom that could provide a homogenous fluidization. Recycle flow was drawn from the top of the reactor by a peristaltic pump (BT600, Prefluid, China). The synthetic phenol solution along with recycle stream was fed upward into the reactor. Synthetic phenolic wastewater was transferred into reactor using a peristaltic pump (BT100, Prefluid, China). Bed expansion in the bioreactor was kept around $100 \%$ with the aid of the recycle flow. The system was embedded in a transparent talc encasement to provide constant temperature at about $25^{\circ} \mathrm{C}$. Produced biogas was released from effluent by aid of a $1000 \mathrm{ml}$ separation funnel which was filled with polyethylene supports up to half of its volume. The liberated biogas was then led to a glass cylindrical collecting tube where the volume of gas was defined by displacement of inside water. The collecting tube was fabricated with an internal diameter of $15 \mathrm{~cm}$ and height of $150 \mathrm{~cm}$. Two sampling ports were installed on AIFBR for monitoring influent and effluent characteristics. The startup and operation periods of AIFBR are illustrated below.

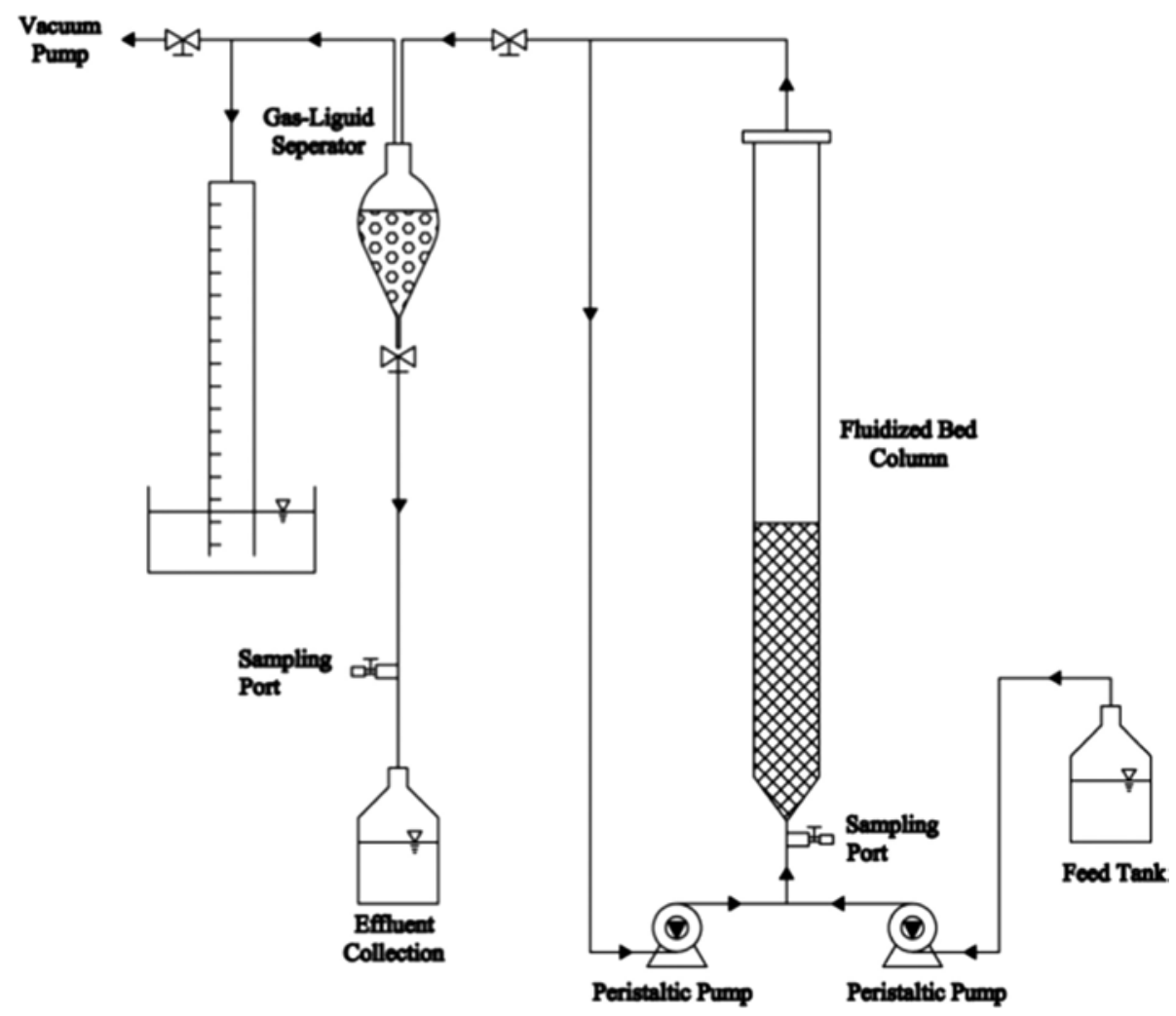

Fig. 1. Schematic diagram of a lab-scale AIFBR used as experimental setup in continuous operations 


\subsection{Inoculums}

The seed inoculums were isolated from the effluents of two industries including coke oven, Isfahan, Iran and pulp and paper, Sari, Iran as well as activated sludge taken from wastewater treatment facility of the latter. An acclimation period of 5 months was implemented to adapt the mixed culture to phenol as sole carbon/ energy source. Adaption steps were performed in $250 \mathrm{ml}$ Erlenmeyer flasks under anaerobic condition in desiccators. During this period, the microorganisms were exposed to increasing phenol concentrations. At the beginning, low concentration of phenol i. e. $100 \mathrm{mg} / \mathrm{l}$ was introduced to the culture in presence of $100 \mathrm{mg} / \mathrm{l}$ glucose as co-substrate. Upon complete removal of $100 \mathrm{mg} / \mathrm{l}$ phenol within 20 days, exposure of the culture to solely phenolic media was started. As phenol removal efficiency of over 95\% was observed, microorganisms were inoculated to a fresh medium containing higher phenol concentration. Inoculums concentration was about $10 \%(\mathrm{v} / \mathrm{v})$. Finally, in duration of 12 days, the adapted culture was capable to degrade 96 and $10 \%$ of 700 and $1000 \mathrm{mg} / \mathrm{l}$ phenol, respectively.

\subsection{Immobilization protocol}

The adapted microorganisms were harvested at the stationary phase, and then entrapped and immobilized in calcium-alginate gel beads. After adding sterilized sodium alginate solution $(2 \% \mathrm{w} / \mathrm{v})$ into cell suspension, the mixture was introduced drop wise into sterilized calcium chloride solution $(6 \% \mathrm{w} / \mathrm{v})$; thus, immobilization procedure was accomplished. Sodium alginate (SIGMA) solution was prepared by adding $10 \mathrm{~g}$ of the alginate powder was added to $500 \mathrm{ml}$ of distilled water. $60 \mathrm{~g}$ of anhydrous granulated form of calcium chloride (Sharlau, Spain) was separately added to 11 of distilled water to prepare calcium chloride bath. A peristaltic pump (BT100, Prefluid, China) and a silicon tube with internal diameter of $1.1 \mathrm{~mm}$ were used to instill the mixture of sodium alginate solution and cell suspension in the calcium chloride bath. Spherical bioparticle beads with average diameter of 3-4 mm were ultimately obtained.

\subsection{Wastewater characteristics}

The synthetic phenolic wastewater was composed of phenol, yeast extract as well as a basal medium which contained all the necessary micro- and macro-elements. The composition of basal medium was (in $\mathrm{mg} / \mathrm{l}$ ): $\mathrm{K}_{2} \mathrm{HPO}_{4}$, 522.54; $\mathrm{KH}_{2} \mathrm{PO}_{4}, 408.27$; and $\mathrm{NH}_{4} \mathrm{Cl}$, 200; $\mathrm{NaCl}, 200 ; \mathrm{KCl}, 200 ; \mathrm{CaCl}_{2} .2 \mathrm{H}_{2} \mathrm{O}, 150 ; \mathrm{MgCl}_{2}$, $100 ; \mathrm{MgSO}_{4} .7 \mathrm{H}_{2} \mathrm{O}, 5 ; \mathrm{FeSO}_{4} \cdot 7 \mathrm{H}_{2} \mathrm{O}, 10 ; \mathrm{CoCl}_{2} \cdot 2 \mathrm{H}_{2} \mathrm{O}$, $0.2 ; \mathrm{NiCl}_{2} .2 \mathrm{H}_{2} \mathrm{O}, 0.2 ; \mathrm{ZnCl}_{2}, 0.2 ; \mathrm{CuCl}_{2} .2 \mathrm{H}_{2} \mathrm{O}, 0.2$; $\mathrm{MnCl}_{2} .4 \mathrm{H}_{2} \mathrm{O}, 0.2 ; \mathrm{NaMoO}_{4} .2 \mathrm{H}_{2} \mathrm{O}, 0.5 ; \mathrm{H}_{3} \mathrm{BO}_{3}, 0.2$; $\mathrm{NaHCO}_{3}, 400$. Concentration of yeast extract was kept constant in the feed at $800 \mathrm{mg} / \mathrm{l}$. By addition of $400 \mathrm{mg} / 1 \mathrm{NaHCO}_{3}, \mathrm{pH}$ of influent was maintained at $6.9 \pm 1$. To prepare synthetic wastewater, phenol and nutrients stock solutions were diluted with distilled water to appropriate concentrations. All of the chemicals were supplied by Merck (Darmstadt, Germany).

\subsection{Startup and operation strategies}

The startup period was carried out to acquaint the immobilized culture to continuous condition in phenol removal plus evaluating the effect of increasing organic load on phenol biodegradation. During startup period, the bioreactor was run at constant hydraulic retention time of $16 \mathrm{~h}$, and phenol influent concentration was gradually increased from 98 to $995 \mathrm{mg} / \mathrm{l}$ in stepwise manner (equivalent to phenol loading rate of 0.15 to $1.48 \mathrm{~g}$ phenol/1.d). Concentration of corresponding COD varied in the range of 234 to $2390 \mathrm{mg} / \mathrm{l}$. The startup period was implemented in 5 operation phases for duration of 65 days. Initially, phase 1 ( $0-5$ days) was performed, where phenol feed and OLR were $98 \mathrm{mg} / 1$ and $0.35 \mathrm{~g} \mathrm{COD} / 1 . \mathrm{d}$, respectively. Second phase started on 6th day and lasted 8 days with influent phenol concentration of $236 \mathrm{mg} / 1$ and OLR of $0.85 \mathrm{~g}$ COD/l.d. At phase 3 (day 15 to day 27), initial phenol concentration was increased to $440 \mathrm{mg} / \mathrm{l}$ (OLR of $1.58 \mathrm{~g} \mathrm{COD} / \mathrm{l} . \mathrm{d})$. In the next 16 days, influent phenol concentration was kept constant at $628 \mathrm{mg} / \mathrm{l}$ which corresponds to OLR of $2.24 \mathrm{~g}$ COD/1.d. In the final phase between day 44 to day 65 (for the last 21 days) phenol concentration increased to $995 \mathrm{mg} / \mathrm{l}$ (OLR of $3.56 \mathrm{~g} \mathrm{COD/1.d).} \mathrm{Under} \mathrm{steady-state} \mathrm{condition,} \mathrm{phenol}$ in feed stream was gradually increased while more than $96 \%$ of phenol was removed.

In the next stage, the effect of hydraulic retention time (HRT) on the process performance was evaluated. Eight experimental runs were carried out with various HRTs including 3, 2, 1, 0.5, 0.3, 0.2, 0.15, 0.1 day. This stage of experiment lasted 77 days; the values of phenol and COD in the influent were maintained at 720 and $1830 \mathrm{mg} / \mathrm{l}$, respectively. The bioreactor was operated at OLRs of $0.61,0.92,1.83,3.72,6.15,9.20,12.25,18.34$ g COD/1.d, which corresponded to the above HRT values. The phenol loading rate was 0.24-7.22 g phenol/1.d. Descending order of HRT was applied in this stage of experiment. Steady-state condition was obtained when phenol concentration in the effluent remained practically constant.

\subsection{Sampling and Analytical methods}

Samples of influent and effluent of the bioreactor were daily analyzed in duplicate. Parameters including chemical oxygen demand (COD), residual phenol, volatile fatty acids (VFAs), total alkalinity (TA) and $\mathrm{pH}$ were determined. COD was measured by closed reflux method. Residual concentrations of phenol were 
defined by direct photometric method using 4-aminoantipyrene and alkaline potassium ferricyanide. Direct titration was applied for determination of VFAs and TA. The above procedures were performed in accordance with Standard Methods for Examination of Water and Wastewater (Eaton et al. 2005). Produced gas was determined by water displacement. $\mathrm{pH}$ measurements were carried out with a $\mathrm{pH}$ meter (pH 212, HANNA, Germany).

\section{Results and discussion}

\subsection{Startup period; effect of phenolic load}

Response of the AIFBR to incremental increase of phenolic load during the startup period was evaluated. The influent and effluent phenol and corresponding COD concentrations, phenol and COD removal, biogas production, VFAs, total alkalinity, and $\mathrm{pH}$ are presented in Figure 2. Startup period was completed for duration of 65 days. This entire operation period was divided into five phases, where stepwise increase in phenol feed from 98 to $995 \mathrm{mg} / \mathrm{l}$ at a constant HRT of

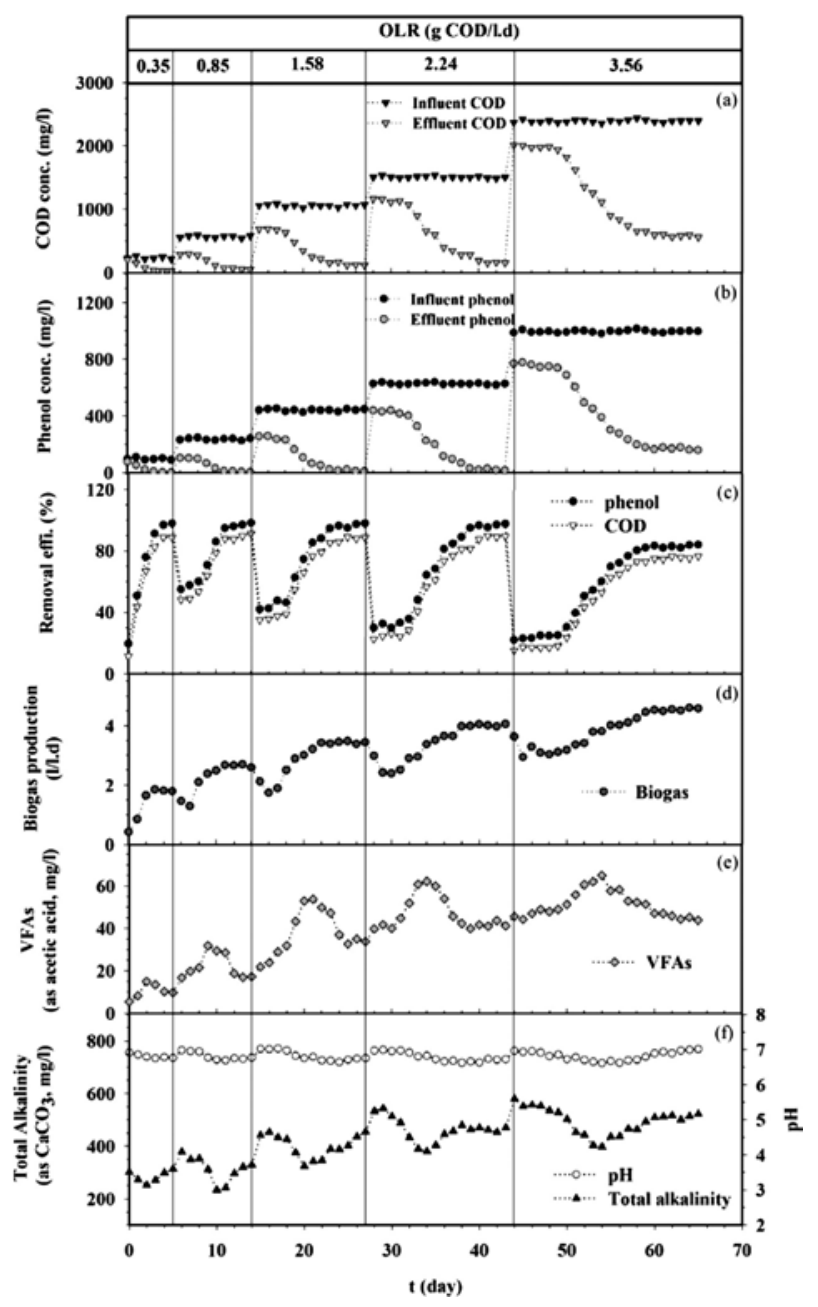

Fig. 2. Response of the AIFBR to increment of phenolic load during startup
$16 \mathrm{~h}$ was investigated. Figure $2(\mathrm{a}-\mathrm{d})$ shows phenol and COD removal and biogas production during the startup period.

In Phase 1 (days 1-5), the AIFBR was fed with phenol and corresponding COD of 98 and $234 \mathrm{mg} / \mathrm{l}$, respectively. The value of OLR was $0.35 \mathrm{~g}$ COD/l.d. Phenol degradation was immediately started. The bioreactor could remove about $44 \mathrm{mg} / \mathrm{l}$ of input phenol at the end of the first day of the experiment. Finally, $98 \%$ of influent phenol and $89 \%$ of influent COD were removed in this phase of experiment. Maximum production of biogas was observed at the final days of the phase when phenol concentration in the effluent remained constant at about $2.6 \mathrm{mg} / \mathrm{l}$. At day 4 , the volumetric biogas rate was 1.81 1/1.d.

Phase 2 was performed within day 6 to day 14 with influent phenol concentration of $236 \mathrm{mg} / \mathrm{l}$, correspondent to COD concentration and OLR of $556 \mathrm{mg} / \mathrm{l}$ and $0.85 \mathrm{~g} \mathrm{COD} / 1$.d, respectively. Although the microorganisms were strictly adapted to phenol concentration of $700 \mathrm{mg} / \mathrm{l}$, a lag period in degradation plus a sudden reduction in removal efficiencies of phenol and COD were diagnosed at the beginning of every single phase.

With increase in phenol concentration up to about $230 \mathrm{mg} / \mathrm{l}$, phenol and COD removal efficiencies reduced to 55 and $48 \%$, respectively. During initial stage of second phase (day 6 to day 9), the phenol concentration in the effluent only decreased to about $102 \mathrm{mg} / \mathrm{l}$. Also biogas production rate decreased from 1.79 1/l.d at day 5 to 1.29 1/1.d at day 7 which is equivalent to $28 \%$ reduction.

At day 11 of experiment, phenol concentration in the effluent degraded to $12.5 \mathrm{mg} / \mathrm{l}$ with removal efficiency of $95 \%$. At the end of this phase, COD removal of $89 \%$ and volumetric biogas rate of 2.67 1/1.d were achieved. In third phase (days 15-27), the OLR was maintained at $0.66 \mathrm{~g} \mathrm{COD} / \mathrm{l}$.d with input phenol concentration of $441 \mathrm{mg} / \mathrm{l}$ and COD of $1050 \mathrm{mg} / \mathrm{l}$ for duration of 12 days. As the influent concentration of phenol increased, the initial lag period in phenol and COD degradation was slightly prolonged. At the initial day of this phase, phenol and COD removal efficiencies drastically decreased to 42 and $35 \%$, respectively. During the first 4 days of $3^{\text {rd }}$ phase, only $46 \%$ of influent phenol was removed; thence the phenol and COD removal efficiencies increased. Moreover, volumetric biogas rate diminished and reached 1.74 1/1.d at day 16. At day 24 of the experiment, phenol and COD removal efficiencies enhanced to 96 and $87 \%$, respectively; accordingly the effluent concentrations of $32 \mathrm{mg} / \mathrm{l}$ phenol and $196 \mathrm{mg} / \mathrm{l}$ COD were determined in this day. In subsequence, the system experienced steady-state condition untill the day 27 th of operation. At the end of this phase, low concentrations of phenol (15 mg/l) and COD (141 mg/l) in the effluent were obtained. Recovery in biogas production from 1.74 to 3.42 1/1.d occurred within days of 16 to 22 of the experiment. Biogas production 
achieved the value of $3.45 \mathrm{1} / 1 . \mathrm{d}$ at the end of this phase. The increment in organic load obviously resulted in further growth of the microorganisms. It seemed that consequent increase in density of the alginate beads had happened. This phase required high recycle flow rate for $100 \%$ fluidization of the support beads could prove the assumption of beads weight increased.

Phase 4 of startup operation was carried out within days 28 to 44 . This phase lasted 17 days; influent phenol concentration was increased to $628 \mathrm{mg} / \mathrm{l}$. Increment in phenol feed led to corresponding COD concentration of $1520 \mathrm{mg} / \mathrm{l}$ and OLR of $2.24 \mathrm{~g} \mathrm{COD} / 1 . d$. In this phase, phenol degradation rate decreased in compare to previous phases. It indicated the substrate inhibition which was imposed by high phenol concentration on the metabolism of the culture. At day 29, the effluent concentrations of $439 \mathrm{mg} / \mathrm{l}$ phenol and $1165 \mathrm{mg} / \mathrm{l}$ COD were observed which were equivalent to removal efficiencies of 30 and $22 \%$, respectively. Removal efficiencies slightly increased to $36 \%$ for phenol and $28 \%$ for COD at day 32. With further increase in removal efficiencies, $64 \%$ of influent phenol concentration was removed and reached $224 \mathrm{mg} / \mathrm{l}$ phenol in the effluent at the day 34th of experiment. Maximum phenol and COD removal of 95 and $87 \%$ were accomplished at the end of this phase. Biogas production rate represented descending trend throughout two initial days of 4th phase. However, it recovered and obtained the steady value of 4.08 1/l.d within days 37 to 43 .

Final phase of startup period was started at day 44 and lasted till day 65 . In this phase, the influent phenol and COD concentration were 995 and $2390 \mathrm{mg} / \mathrm{l}$, respectively. Therefore, the value of OLR was kept constant at $3.56 \mathrm{~g} \mathrm{COD} / 1 . d$. Due to intense inhibition of high phenol concentration, its removal efficiencies showed a dramatic decrease to $22 \%$ at first day of this phase. At the same day, COD removal of $15 \%$ was obtained. For 7 days at the beginning of this phase, no significant reduction in phenol and COD concentration was observed. At day 56, phenol removal efficiency increased to $72 \%$ which corresponded to effluent phenol and COD concentrations of 277 and $839 \mathrm{mg} / \mathrm{l}$, respectively. The AIFBR completed final phase in stable condition. Steady-state condition was obtained at the time interval between the days 58 to 65 with a phenol effluent concentration of $140 \mathrm{mg} / \mathrm{l}$ correspond to removal efficiencies of $84 \%$ for phenol and $79 \%$ for COD. The volumetric biogas rate of $4.551 / 1$.d was achieved at the end of 5 th phase which was the highest value for the startup period. Carbajo and coworkers (Carbajo et al. 2010) achieved the maximum volumetric biogas rate of $4.4 \mathrm{l} / \mathrm{l}$.d with average yield of $0.281 \mathrm{CH}_{4} / \mathrm{g}$ COD removed in an AFBR while the OLR was progressively increased to $15.46 \mathrm{~g} \mathrm{COD} / \mathrm{l}$.d. However, they observed that with increase in OLR biogas composition was changed; the percentage of $\mathrm{CO}_{2}$ increased as the $\mathrm{CH}_{4}$ percentage decreased.

\subsection{Variation of VFAs during startup period}

The concentrations of effluent volatile fatty acids measured as acetic acid during phenolic waste treatment are presented in Figure 2e. Stepwise increase in influent phenol led to ascending attitude in VFAs concentration at the beginning of every operation phase; subsequently after obtaining a peak value, a gradual decrease was followed in VFAs value. From one phase to another, the peak concentration of VFAs was increased as phenolic load was added. Decrease in VFAs concentration may be correlated to the methanogenic stage when VFAs and organic compounds were utilized and stable end product of methane and carbon dioxide were formed. During startup operation, VFAs concentration varied in the range of 5.5 to $65 \mathrm{mg} / \mathrm{l}$. At the end phase of startup, the highest value of effluent VFAs i.e. $65 \mathrm{mg} / \mathrm{l}$ was observed. Bakhshi et al. (Bakhshi et al. 2011) reported the range of 34-64.7 mg/l for VFAs concentration as the value of OLR increased from 0.25 to $2.5 \mathrm{~g} \mathrm{COD} / 1$.d during phenol treatment in UAPB. Subramanyam and Mishara (Subramanyam et al. 2007) found out that the value of VFAs which was produced during catechol degradation in a UASB varied from 15 to $65 \mathrm{mg} / \mathrm{l}$. However, in presence of resorcinol and catechol, VFAs concentration of 30 to $63.5 \mathrm{mg} / \mathrm{l}$ was observed in the UASB (Subramanyam et al. 2008); that may be due to intense toxicity of two inhibitory substrates and retardation in methanogenic activity which resulted in consequent accumulation of VFAs. In this period of the operation, the ratio of VFAs/TA varied between $0.03-0.16$. It is according to the reported data in literature (Subramanyam et al. 2007; Subramanyam et al. 2008; Bakhshi et al. 2011).

\section{3. $\mathrm{pH}$ and alkalinity during startup period}

Figure $2 \mathrm{f}$ shows the variation of $\mathrm{pH}$ and total alkalinity (TA) in the effluent of AIFBR during startup operation period. Anaerobic systems are sensitive to $\mathrm{pH}$ variation. Production of organic acids and VFAs either in hydrolysis or acidogenesis periods of anaerobic digestion can lead to acidic condition (Rittmann et al. 2001; Bakhshi et al. 2011). The pH values of below or above the range of 6.5-7.1 may adversely affects the biological process by disturbance and interruption in bacterial activity, especially in methanogenesis (Subramanyam et al. 2008). Thus, the value of $\mathrm{pH}$ in AIFBR was adjusted between $6.8 \pm 0.2$ by adding $\mathrm{NaHCO}_{3}$ with the concentration of $400 \mathrm{mg} / \mathrm{l}$. Subramanyam and Mishara (Subramanyam et al. 2007) observed instability in the $\mathrm{pH}$ of a UASB degrading phenolic waste in absence of alkalinity. The effluent alkalinity as $\mathrm{CaCO}_{3}$ in the AIFBR was 233 to $579 \mathrm{mg} / \mathrm{l}$. As VFAs concentration increased at the beginning of every phase of startup operation, the effluent alkalinity contributed a diminution, though, it was enhanced later. 


\subsection{Effect of HRT on the AIFBR performance}

In this period of operation, the AIFBR was continuously fed with a solution of $720 \mathrm{mg} / \mathrm{l}$ phenol and corresponding COD of $1830 \mathrm{mg} / \mathrm{l}$ for 77 days. The feed with phenol concentration of $700 \mathrm{mg} / \mathrm{l}$ was well treated due to high performance of the AIFBR at the similar phenolic load during the startup period. The HRT initially was fixed at 3 days with OLR of $0.61 \mathrm{~g}$ COD/1.d; it was progressively declined from 3 to 0.1 days in eight experimental runs between the days 65 to 142 of the experiment. As a result, the OLR ranged between 0.61-18.34 g COD/1.d. For each HRT, removal capacity of phenol and COD in the bioreactor were monitored periodically. Once phenol and COD concentrations in the effluent remained constant, HRT was decreased to a lower value.

Figure 3 shows the performance of the AIFBR at different HRTs, in terms of the influent and effluent concentrations and removal efficiencies of phenol and COD, biogas production, the effluent VFAs, $\mathrm{pH}$ and

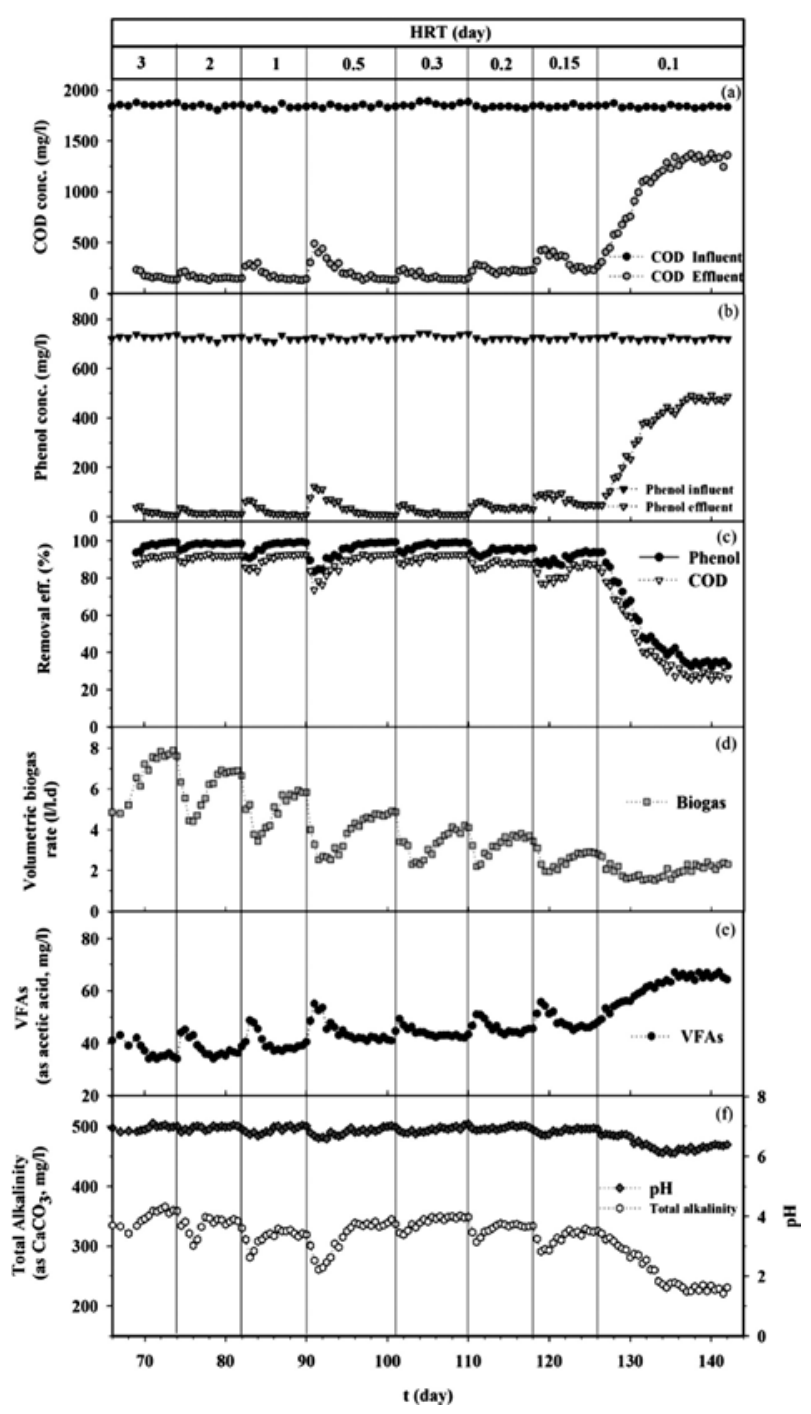

Fig. 3. Effect of decreasing retention time on the AIFBR performance alkalinity. The trend of organic load reduction with respect to time in term of decreasing HRT is shown in Figure 3. Reduction of HRT means the bioreactor operates faster. In fact, this figure represents the actual data obtained with respect to HRT.

In three initial runs of the experiments when HRT varied between 1-3 days, the AIFBR presented an appropriate performance; the bioreactor immediately reached a very stable condition due to long HRTs. Finally, the effluent phenol and COD concentrations found to be less than 7 and $145 \mathrm{mg} / 1$, respectively. In these three sets of experimental runs, the removal efficiencies of over $98 \%$ for phenol and above 91\% for COD were achieved.

Nevertheless, the system required a prolonged time interval for removing phenol from the effluent at HRT of 0.5 day. With decrease in the value of HRT to 0.5 day, the bioreactor showed instability in 6 initial days of the phase (days 90-96). The concentration of phenol in the effluent increased from $8 \mathrm{mg} / 1$ at day 90 to $121 \mathrm{mg} / \mathrm{l}$ at day 91 . At the same day $\left(91^{\text {st }}\right.$ day), the effluent concentration of $488 \mathrm{mg} / \mathrm{l}$ for COD was determined. However, the AIFBR finally reached steady-state condition between the days of 96 to 101 . At HRT of 0.5 day, the influent phenol and COD were removed with efficiencies of 97 and $90 \%$, respectively. During the experimental runs of 5 to 7 (HRT of 0.3 to 0.15 day), the bioreactor was able to obtain high removal efficiencies for phenol and COD with average values of 95 and $89 \%$, respectively. However, the stable removal efficiency of phenol and COD at the end of each run were progressively increased with further decrease in the value of HRT. For the HRT of 0.15 days (OLR of $12.25 \mathrm{~g}$ COD/l.d), the performance of the bioreactor was initially disturbed for 4 days; the phenol and COD concentrations of effluent were 96 and $420 \mathrm{mg} / \mathrm{l}$, respectively. Although the system showed an appropriate behavior in phenol elimination at day 123; but a decrease in final removal efficiencies was observed for phenol (93\%) and COD (86\%) rather than former runs. Residual phenol of $48 \mathrm{mg} / \mathrm{l}$ and COD of $235 \mathrm{mg} / \mathrm{l}$ were determined at the HRT of 0.15 days. However, as the value of HRT was declined to 0.1 day, the bioreactor intensely experienced an unstable condition. At the end run, progressive increase in undegraded phenol and COD concentrations in the effluent was observed and biomass washout rapidly occurred. The average concentration of $17 \mathrm{mg} / \mathrm{l}$ for phenol and $173 \mathrm{mg} / \mathrm{l}$ for COD in the effluent of the AIFBR was detected for the HRTs of 3 to 0.15 days. Biogas production was continuously monitored when the HRT was decreased during 77 days of the experiment (Figure 3d). As the HRT decreased and correspondent increase in OLR happened, biogas production rate was diminished. When HRT was fixed to a lower value, a sharp drop in biogas production occurred and volumetric biogas rate went through a minimum value. However, it subsequently followed an increasing trend to a stable condition. The maximum biogas 
production e.g. 7.04 1/l.d was observed in the first run with the HRT of 3 days. At the end of run, no significant biogas production (1.72-2.38 1/l.d) was observed due to severe instability in the performance of the AIFBR.

The AIFBR responded successfully to phenol biodegradation at high OLRs and low HRTs in compare to other studies in the literature (see Table 2). The long HRT of 10.38 days was applied in an ABR for pnitrophenol degradation where removal efficiency of 99 was achieved at loading rate as high as $33.9 \mathrm{~g}$ p-nitrophenol $/ \mathrm{m}^{3}$.d. Khodadoust et al. (Khodadoust et al. 1997) achieved $99.9 \%$ removal of pentachlorophenol in anaerobic granulated activate carbon fluidized bed reactor (GAC-AFBR) at an empty bed contact time as low as $9.3 \mathrm{~h}$. In presence of poly aromatic hydrocarbons, high degradation efficiency of pentachlorophenol (i.e. 99.8\%) also occurred in the GAC-AFBR with $46.5 \%$ average conversion to its dechlorination intermediates. Also low concentrations of influent poly aromatic hydrocarbons were indentified in the effluent (Koran et al. 2001). Adequate treatment of phenolic wastewater was reported in an AFBR at constant HRT of 0.43 days and OLR of up to $15.46 \mathrm{~g} \mathrm{COD} / 1 . \mathrm{d}$ by Carbajo et al. (Carbajo et al. 2010).

\subsection{Effect of HRT on the Variation of VFAs}

The variation of VFAs in the effluent between the days of 65 and 142 are depicted in Figure 3e. VFAs concentration was progressively increased as the HRT decreased. Increase in the concentration of VFAs at the beginning of each run could be explained by accumulation of organic acids due to facing with a higher value of HRT. But, the system was later adapted to the new situation when HRTs ranged between 0.15-3 days and reached to a very stable condition at the end of any individual run. The effluent VFAs varied in the range of $36-66 \mathrm{mg} / \mathrm{l}$. The maximum value of VFAs as acetic acid, i.e. $66 \mathrm{mg} / 1$, was obtained at HRT of 0.1 days; that may be due to the failure in the AIFBR. The parameter VFAs/TA was between 0.09-0.2 as the HRT decreased from 3 to 0.15 days, though it increased to 0.24 at the final run which indicated high concentrations of VFAs as well as low activity of methanogens.

\subsection{Effect of HRT on the $\mathrm{pH}$ and alkalinity}

The value of $\mathrm{pH}$ and alkalinity relevant to decrease in HRT are shown in Figure 3f. Within the runs of 1 to 7 with HRTs of 0.15-3 days, when the system presented a favorable behavior in phenol removal, $\mathrm{pH}$ and alkalinity of the effluent was in the range of 6.597.11 and $261-362 \mathrm{mg} / \mathrm{l}$, respectively. At the end run with HRT of 0.1 days, the value of $\mathrm{pH}$ dropped to 6.11 at day 135. Alkalinity concentration at day 126 decreased from 325.5 to $227 \mathrm{mg} / \mathrm{l}$ at day 140 . Addition of $400 \mathrm{mg} / \mathrm{l} \mathrm{NaHCO}$ was accomplished for the $\mathrm{pH}$ stability, though, addition of this content of alkalinity could not counterbalance the acidic condition at HRT of 0.1 days because of the high accumulation of VFAs.

\section{Conclusion}

1. Phenol containing wastewater was effectively treated in as anaerobic immobilized fluidized bed reactor (AIFBR) at high organic loading rates (i.e. $0.35-12.25 \mathrm{~g} \mathrm{COD} / 1 . \mathrm{d})$ with a culture entrapped in calcium alginate beads as biocatalyst.

2. At startup period in which phenolic load was stepwise increased, over $95 \%$ of phenol and $87 \%$ of COD was removed at phenol loading of 98 $630 \mathrm{mg} / \mathrm{l}$, OLR of $0.35-2.44 \mathrm{~g} \mathrm{COD} / \mathrm{l} . \mathrm{d}$ and phenol loading rate of $0.15-0.94 \mathrm{~g}$ phenol/1.d. However, a decrease in phenol and COD removal to $84 \%$ and $79 \%$ at phenol feed of $995 \mathrm{mg} / \mathrm{l}$ was observed due to intense substrate inhibition.

3. The highest biogas production of $4.551 / 1 . \mathrm{d}$ occurred at $995 \mathrm{mg} / \mathrm{l}$ phenol during startup.

4. In this period, VFAs, $\mathrm{pH}$ and alkalinity in the effluent of the AIFBR varied between 5.5$65 \mathrm{mg} / \mathrm{l}, 6.5-7.1$ and $233-579 \mathrm{mg} / \mathrm{l}$, respectively. The value of VFAs/TA ratio was 0.03 to 0.16 .

5. The AIFBR was favorably tolerated the decrease in hydraulic retention time from 3 days to 0.15 day. In this operation period, removal efficiency of $93-98 \%$ for phenol and $86-91 \%$ for COD was obtained for constant phenol loading of $720 \mathrm{mg} / \mathrm{l}$ and OLRs of $0.61-12.25 \mathrm{~g} \mathrm{COD} / \mathrm{l} . \mathrm{d}$. However, further decrease of HRT to 0.1 days (OLR of $18.34 \mathrm{~g} \mathrm{COD/1.d)} \mathrm{led} \mathrm{to} \mathrm{instability} \mathrm{and}$ failure in reactor performance.

6. For HRT of 0.1 days, VFAs/TA was 0.24 which showed a disruption in anaerobic process due to low HRT.

\section{Acknowledgment}

The authors are grateful for the facilities provided to carry out present research in Biotechnology Research center, Babol Noshirvani University of Technology.

\section{References}

Alemzadeh, I.; Vossoughi, F.; Houshmandi, M. 2002. Phenol biodegradation by rotating biological contactor, Biochemical Engineering Journal 11(1): 19-23. http://dx.doi.org/10.1016/S1369-703X(02)00011-6

Arutchelvan, V.; Kanakasabai, V.; Elangovan, R.; Nagarajan, S.; Muralikrishnan, V. 2006. Kinetics of high strength phenol degradation using Bacillus brevis, Journal of Hazardous Materials 129(1-3): 216-222. http://dx.doi.org/10.1016/j.jhazmat.2005.08.040

Asadi, M.; Ebrahimi, A.; Najafpour, G. H. D. 2009a. Dairy wastewater treatment using three-stage rotating biological contactor (NRBC), International Journal of Engineering 22(2): 107-114. 
Asadi, M.; Najafpour, G. D.; Hashemiyeh, B. A.; Mohammadi, M. 2009b. Removal of Acetone from Contaminated Air in Biofilter using Pseudomonas putida, AmericanEurasian J. Agric. \& Environ. Sci. 5(5): 712-719.

Bakhshi, Z.; Najafpour, G.; Navayi, N. B.; Kariminezhad, E.; Pishgar; Moosavi, N. 2011. Recovery of UAPB from high organic load during startup for phenolic wastewater treatment, Chemical Industry and Chemical Engineering Quarterly 17(4): 517-524. http://dx.doi.org/10.2298/CICEQ110428037B

Bertin, L.; Berselli, S.; Fava, F.; Petrangeli-Papini, M.; Marchetti, L. 2004. Anaerobic digestion of olive mill wastewaters in biofilm reactors packed with granular activated carbon and "Manville" silica beads, Water Research 38(14-15): 3167-3178. http://dx.doi.org/10.1016/j.watres.2004.05.004

Borja, R.; Banks, C. J. 1995. Response of an anaerobic fluidized bed reactor treating ice-cream wastewater to organic, hydraulic, temperature and $\mathrm{pH}$ shocks, Journal of Biotechnology 39(3): 251-259. http://dx.doi.org/10.1016/0168-1656(95)00021-H

Carbajo, J.; Boltes, K.; Leton, P. 2010. Treatment of phenol in an anaerobic fluidized bed reactor (AFBR): continuous and batch regime, Biodegradation 21(4): 603-613. http://dx.doi.org/10.1007/s10532-010-9328-1

Carlo, R.; Laura, A. 2008. Technologies for the removal of phenol from fluid streams: a short review of recent developments, Journal of Hazardous Materials 160(2-3): 265-288.

Eaton, A.; Franson, M. 2005. Standard methods for the examination of water \& wastewater, Amer. Public Health Assn.

El-Naas, M.; Al-Muhtaseb, S.; Makhlouf, S. 2009. Biodegradation of phenol by Pseudomonas putida immobilized in polyvinyl alcohol (PVA) gel, Journal of Hazardous Materials 164(2-3): 720-725. http://dx.doi.org/10.1016/j.jhazmat.2008.08.059

Fang, H.; Liang, D.; Zhang, T.; Liu, Y. 2006. Anaerobic treatment of phenol in wastewater under thermophilic condition, Water Research 40(3): 427-434. http://dx.doi.org/10.1016/j.watres.2005.11.025

Firozjaee, T. T.; Najafpour, G. D.; Khavarpour, M.; Bakhshi, Z.; Pishgar, R.; Mousavi, N. 2011. Phenol Biodegradation Kinetics in an Anaerobic Batch Reactor. World Environmental and Water Resources Congress, California, American Society of Civil Engineers (ASCE).

Gali, V. S.; Kumar, P.; Mehrotra, I. 2006. Biodegradation of phenol with wastewater as a cosubstrate in upflow anaerobic sludge blanket, Journal of Environmental Engineering 132(11): 1539-1542. http://dx.doi.org/10.1061/(ASCE)0733-9372(2006) 132:11(1539)

Gonzalez, G.; Herrera, G.; García, M.; Pena, M. 2001a. Biodegradation of phenolic industrial wastewater in a fluidized bed bioreactor with immobilized cells of Pseudomonas putida, Bioresource Technology 80(2): 137142. http://dx.doi.org/10.1016/S0960-8524(01)00076-1

Gonzalez, G.; Herrera, M.; García, M.; Pena, M. 2001 b. Biodegradation of phenol in a continuous process: comparative study of stirred tank and fluidized-bed bioreactors, Bioresource Technology 76(3): 245-251. http://dx.doi.org/10.1016/S0960-8524(00)00092-4
Khodadoust, A. P.; Wagner, J. A.; Suidan, M. T.; Brenner, R. C. 1997. Anaerobic treatment of PCP in fluidized-bed GAC bioreactors, Water Research 31(7): 1776-1786. http://dx.doi.org/10.1016/S0043-1354(97)00005-5

Koran, K.; Suidan, M.; Khodadoust, A.; Sorial, G.; Brenner, R. 2001. Effectiveness of an anaerobic granular activated carbon fluidized-bed bioreactor to treat soil wash fluids: a proposed strategy for remediating $\mathrm{PCP} / \mathrm{PAH}$ contaminated soils, Water Research 35(10): 2363-2370. http://dx.doi.org/10.1016/S0043-1354(00)00475-9

Kuscu, O. S.; Sponza, D. T. 2005. Performance of anaerobic baffled reactor (ABR) treating synthetic wastewater containing p-nitrophenol, Enzyme and Microbial Technology 36(7): 888-895. http://dx.doi.org/10.1016/j.enzmictec.2005.01.001

Kuyukina, M. S.; Ivshina, I. B.; Serebrennikova, M. K.; Krivorutchko, A. B.; Podorozhko, E. A.; Ivanov, R. V.; Lozinsky, V. I. 2009. Petroleum-contaminated water treatment in a fluidized-bed bioreactor with immobilized Rhodococcus cells, International Biodeterioration \& Biodegradation 63(4): 427-432. http://dx.doi.org/10.1016/j.ibiod.2008.12.001

Kwon, K. H.; Yeom, S. H. 2009. Optimal microbial adaptation routes for the rapid degradation of high concentration of phenol, Bioprocess and Biosystems Engineering 32(4): 435-442. http://dx.doi.org/10.1007/s00449-008-0263-z

Latkar, M.; Swaminathan, K.; Chakrabarti, T. 2003. Kinetics of anaerobic biodegradation of resorcinol catechol and hydroquinone in upflow fixed film-fixed bed reactors, Bioresource Technology 88(1): 69-74. http://dx.doi.org/10.1016/S0960-8524(02)00261-4

Lohi, A.; Alvarez Cuenca, M.; Anania, G.; Upreti, S.; Wan, L. 2008. Biodegradation of diesel fuel-contaminated wastewater using a three-phase fluidized bed reactor, Journal of Hazardous Materials 154(1-3): 105-111. http://dx.doi.org/10.1016/j.jhazmat.2007.10.001

Majumder, P. S.; Gupta, S. 2008. Degradation of 4-chlorophenol in UASB reactor under methanogenic conditions, Bioresource Technology 99(10): 4169-4177. http://dx.doi.org/10.1016/j.biortech.2007.08.062

Metcalf, E.; Eddy, H. 2003. Wastewater engineering: treatment and reuse. McGraw-Hill Book Company.

Mousavi, N.; Najafpour, G. D.; Bakhshi, Z.; Pishgar, R. 2011. Performance of Anaerobic Baffled Reactor for Biodegradation of Phenol, Iranica Journal of Energy and Environment (IJEE) 2(3): 229-234.

Moussavi, G.; Mahmoudi, M.; Barikbin, B. 2009. Biological removal of phenol from strong wastewaters using a novel MSBR, Water Research 43(5): 1295-1302. http://dx.doi.org/10.1016/j.watres.2008.12.026

Nair, I. C.; Jayachandran, K.; Shashidhar, S. 2007. Treatment of paper factory effluent using a phenol degrading Alcaligenes sp. under free and immobilized conditions, Bioresource Technology 98(3): 714-716. http://dx.doi.org/10.1016/j.biortech.2006.02.034

Nuhoglu, A.; Yalcin, B. 2005. Modelling of phenol removal in a batch reactor, Process Biochemistry 40(3-4): 12331239. http://dx.doi.org/10.1016/j.procbio.2004.04.003 
Perez, M.; Rodriguez-Cano, R.; Romero, L.; Sales, D. 2007. Performance of anaerobic thermophilic fluidized bed in the treatment of cutting-oil wastewater, Bioresource Technology 98(18): 3456-3463. http://dx.doi.org/10.1016/j.biortech.2006.11.005

Rittmann, B.; McCarty, P. 2001. Environmental biotechnology: principles and applications. New York, McGraw-Hill.

Saghafi, S.; Bakhshi, Z.; Najafpour, G. D.; Kariminezhad, E.; Rad, H. A. 2010. Biodegradation of Toluene and Xylene in an UAPB Bioreactor with Fixed Film of Pseudomonas putida, American-Eurasian Journal of Agricultural \& Environment Sciences 9(1): 01-07.

Scully, C.; Collins, G.; O'Flaherty, V. 2006. Anaerobic biological treatment of phenol at $9.5-15 \mathrm{C}$ in an expanded granular sludge bed (EGSB)-based bioreactor, Water Research 40(20): 3737-3744. http://dx.doi.org/10.1016/j.watres.2006.08.023

Șen, S.; Demirer, G. 2003. Anaerobic treatment of real textile wastewater with a fluidized bed reactor, Water research 37(8): 1868-1878. http://dx.doi.org/10.1016/S0043-1354(02)00577-8

Sowmeyan, R.; Swaminathan, G. 2008. Performance of inverse anaerobic fluidized bed reactor for treating high strength organic wastewater during start-up phase, Bioresource Technology 99(14): 6280-6284. http://dx.doi.org/10.1016/j.biortech.2007.12.001

Subramanyam, R.; Mishra, I. 2007. Biodegradation of catechol (2-hydroxy phenol) bearing wastewater in an UASB reactor, Chemosphere 69(5): 816-824. http://dx.doi.org/10.1016/j.chemosphere.2007.04.064

Subramanyam, R.; Mishra, I. 2008. Co-degradation of resorcinol and catechol in an UASB reactor, Bioresource Technology 99(10): 4147-4157. http://dx.doi.org/10.1016/j.biortech.2007.08.060
Tziotzios, G.; Teliou, M.; Kaltsouni, V.; Lyberatos, G.; Vayenas, D. 2005. Biological phenol removal using suspended growth and packed bed reactors, Biochemical Engineering Journal 26(1): 65-71. http://dx.doi.org/10.1016/j.bej.2005.06.006

Vázquez, I.; Rodriguez, J.; Maranon, E.; Castrillón, L.; Fernandez, Y. 2006. Study of the aerobic biodegradation of coke wastewater in a two and three-step activated sludge process, Journal of Hazardous Materials 137(3): 16811688. http://dx.doi.org/10.1016/j.jhazmat.2006.05.007

Veeresh, G. S.; Kumar, P.; Mehrotra, I. 2005. Treatment of phenol and cresols in upflow anaerobic sludge blanket (UASB) process: a review, Water Research 39(1): 154170. http://dx.doi.org/10.1016/j.watres.2004.07.028

Wang, W.; Han, H.; Yuan, M.; Li, H.; Fang, F.; Wang, K. 2010. Treatment of coal gasification wastewater by a twocontinuous UASB system with step-feed for COD and phenols removal, Bioresource Technology 102(9): 54545460 .

http://dx.doi.org/10.1016/j.biortech.2010.10.019

Yan, J.; Jianping, W.; Hongmei, L.; Suliang, Y.; Zongding, H. 2005. The biodegradation of phenol at high initial concentration by the yeast Candida tropicalis, Biochemical Engineering Journal 24(3): 243-247. http://dx.doi.org/10.1016/j.bej.2005.02.016

Yan, J.; Jianping, W.; Jing, B.; Daoquan, W.; Zongding, H. 2006. Phenol biodegradation by the yeast Candida tropicalis in the presence of $\mathrm{m}$-cresol, Biochemical Engineering Journal 29(3): 227-234. http://dx.doi.org/10.1016/j.bej.2005.12.002

Roya PISHGAR has a Master of Science of Environmental Engineering and a Bachelor of Science of Civil Engineering at the School of Civil Engineering, Babol Noshirvani University of Technology. Has published 6 journal papers and 5 conference papers and has attended the $1^{\text {st }}$ Environmental Remediation Technologies Conference. Research interests include: water and wastewater treatment, waste management, air pollution.

Ghasem D. NAJAFPOUR is a Professor of Chemical Engineering at the Babol Noshirvani University of Technology, Iran. An Associate Professor of Chemical Engineering at the Universiti of Sains Malaysia (1998-2005). An Associate Professor at the Chemical Engineering Department, University of Mazandaran, Iran (1995-1998). An Assistant Professor at the Department of Chemical Engineering, University of Mazandaran, Iran (1983-1995). Visiting Professor, Sabbatical Leave \& Research Scientist at the Department of Chemical Engineering, University of Arkansas, USA (1990-1993). Teaching Assistant at the University of Arkansas, USA (19761980, 1981-1983). Head of Biotechnology Research Center and Editor in Chief of IJE, IJEE, MEJSR, JAES and WASJ. Has published 312 National, International ISI indexed Journals and Proceedings and 9 books.

Bahram NAVAYI NEYA is an Associate Professor of Civil Engineering at the Babol Noshirvani University of Technology, Iran. He has a $\mathrm{PhD}$ of Civil Engineering-Hydraulic Structures at the Moscow Power Engineering Institute, Russia; Master of Science of Civil Engineering-Hydraulic Structures; Bachelor of Science of Civil Engineering at the Amir Kabir university of Technology (Tehran Polytechnic), Iran. Has published 19 English and Persian papers, 53 national and international conference papers and 3 books. Research interests include: design and analysis of water network, elasticity and plasticity theories, plates and shells, concrete behavioral models, design and analysis of concrete dams.

Nafise MOUSAVI. Has a Master of Science of Environmental engineering and a Bachelor of Science of Civil engineering at the School of Civil Engineering, Babol Noshirvani University of Technology, Babol, Mazandaran, Iran. Has published 6 journal papers and 5 conference papers and has attended the $1^{\text {st }}$ Environmental Remediation Technologies Conference). Research interests include: water and wastewater treatment, waste management, air pollution.

Zeinab BAKHSHI. Has a Master's degree of Science of Environmental engineering and a Bachelor's degree of Civil engineering at the School of Civil Engineering, Babol Noshirvani University of Technology, Babol, Mazandaran, Iran. Has published 8 journal papers and 5 conference papers. Research interests include: water and wastewater treatment, membrane technology. 